\title{
PENGEMBANGAN PENDIDIKAN KARAKTER DAN BUDAYA BANGSA BERWAWASAN KEARIFAN LOKAL
}

\author{
James Ronal Tambunan \\ Correspondent Email: jamesronaldtambunan@gmail.com
}

\begin{abstract}
Abstrak
Dunia pendidikan saat ini masih menampung banyak masalah. Program pemerataan dan peningkatan kualitas pendidikan belum menampakkan hasil seperti yang diharapkan. Jumlah anak usia pendidikan dasar yang berada di luar sistem pendidikan nasional masih sangat besar. Kualitas pendidikan pun masih relatif rendah. Sumberdaya manusia yang berkarakter sebagaimana diungkapkan di atas dapat dicapai melalui pendidikan yang berorientasi pada pembentukan jiwa entrepreneurship, yaitu jiwa keberanian dan ke-mauan menghadapi problema hidup dan kehidupan secara wajar, jiwa kreatif untuk mencari solusi dan mengatasi problema tersebut, dan jiwa mandiri dan tidak ber-gantung pada orang lain. Salah satu jiwa entrepreneurship yang perlu dikembangkan melalui pendidikan adalah karakter yang bersumber dari budaya bangsa. Pendidikan karakter berpijak dari karakter dasar manusia, yang bersumber dari nilai moral universal (bersifat absolut) yang disebut sebagai kaidah emas (the golden rule). Pendidikan karakter dapat memiliki tujuan yang pasti apabila berpijak dari nilai-nilai karakter dasar sebagaimana diungkapkan di atas. Penyelenggaraan pendidikan karakter di sekolah harus berpijak pada nilai-nilai karakter dasar, yang selanjutnya dikembangkan menjadi nilai-nilai yang lebih banyak atau lebih tinggi (yang bersifat tidak absolut atau bersifat relatif) sesuai dengan kebutuhan, kondisi, dan lingkungan sekolah itu sendiri (Sudrajad, 2010). Pembentukan karakter dimulai dari keinginan untuk mengetahui serta melakukan hal yang baik agar tercipta kebiasaan, baik dihati, pikiran, maupun perilaku. Dalam membentuk karakter positif, peserta didik perlu mengetahui alasan mengapa berbuat baik, merasakan hal yang baik, dan melakukan hal yang baik. Perlunya lingkungan belajar yang positif dan peduli yang ditandai dengan penuh kasih sayang, penuh dengan kepedulian, kompetensi guru dan staf sekolah yang memberikan inspirasi dan bebas dari berbagai bentuk tindak kekerasan, serta pendidikan yang inklusif.
\end{abstract}

Kata Kunci: Pendidikan Karakter, Jiwa Enterpreneurship, Induktif.

\section{PENDAHULUAN}

Dunia pendidikan saat ini masih menampung banyak masalah. Program pemerataan dan peningkatan kualitas pendidikan belum menampakkan hasil seperti yang diharapkan. Jumlah anak usia pendidikan dasar yang berada di luar sistem pendidikan nasional masih sangat besar. Kualitas 
pendidikan pun masih relatif rendah. Di pihak lain, tantangan di berbagai bidang kehidupan semakin berat. Perkembangan ilmu pengetahuan dan teknologi, khususnya di bidang informasi, komunikasi, dan transportasi sangat pesat, eskalasi pasar bebas antarnegara dan bangsa se-makin meningkat, dan iklim kompetisi di berbagai aspek kehidupan semakin ketat. Masih banyak lagi masalah lain yang memerlukan penyelesaian seperti demokratisasi, hak asasi manusia, serta pe-nyelenggaraan kehidupan bermasyarakat, berbangsa, dan bernegara yang adil dan terbuka.

Dunia pendidikan harus mampu berperan aktif menyiapkan sumberdaya manusia terdidik yang mampu menghadapi berbagai tantangan kehidupan, baik lokal, regional, nasional maupun internasional. Ia tidak cukup hanya menguasai teori-teori, tetapi juga mau dan mampu menerapkannya dalam kehidupan sosial. Ia tidak hanya mampu menerapkan ilmu yang diperoleh di bangku sekolah/kuliah, tetapi juga mampu memecahkan berbagai persoalan yang dihadapi dalam kehidupan sehari-hari.

Sumberdaya manusia yang berkarakter sebagaimana diungkapkan di atas dapat dicapai melalui pendidikan yang berorientasi pada pembentukan jiwa entrepreneurship, yaitu jiwa keberanian dan kemauan menghadapi problema hidup dan kehidupan secara wajar, jiwa kreatif untuk mencari solusi dan mengatasi problema tersebut, dan jiwa mandiri dan tidak ber-gantung pada orang lain. Salah satu jiwa entrepreneurship yang perlu dikembangkan melalui pendidikan adalah karakter yang bersumber dari budaya bangsa.

Pendidikan yang berbasis karakter dan budaya bangsa adalah pendidikan yang menerapkan prinsip-prinsip dan metodologi ke arah pembentukan karakter anak bangsa pada peserta didiknya melalui kurikulum terintegrasi yang dikembang-kan di sekolah.

Kerangka pengembangan karakter dan budaya bangsa melalui pembelajaran di kalangan tenaga pendidik dirasakan sangat penting. Sebagai agen perubahan, pendidik diharapkan mampu menanamkan ciri-ciri, sifat, dan watak serta jiwa mandiri, tanggung jawab, dan cakap dalam kehidupan kepada peserta didiknya. Di samping itu, karakter tersebut juga sangat diperlukan bagi seorang pendidik karena melalui jiwa ini, para pendidik akan me-miliki orientasi kerja yang lebih efisien, kreatif, inovatif, produktif serta mandiri.

\subsection{PENTINGNYA PENDIDIKAN KARAKTER DAN BUDAYA BANGSA}

Pendidikan saat ini hanya mengedepankan penguasaan aspek keilmuan dan kecerdasan peserta didik. Jika peserta didik sudah mencapai nilai atau lulus dengan nilai akademik memadai/di atas KKM (Kriteria Ketuntasan Minimal), pendidikan dianggap sudah berhasil. Pembentukan karakter dan nilai-nilai budaya bangsa di dalam diri peserta didik semakin terping-girkan. Rapuhnya karakter dan budaya dalam kehidupan berbangsa bisa mem-bawa kemunduran peradaban bangsa. Padahal, kehidupan masyarakat yang me-miliki karakter dan budaya yang kuat akan semakin memperkuat eksistensi suatu bangsa dan negara. 
Pengembangan pendidikan berbasis karakter dan budaya bangsa perlu menjadi program nasional. Dalam pendidikan, pem-bentukan karakter dan budaya bangsa pada peserta didik tidak harus masuk kurikulum. Nilai-nilai yang ditumbuhkem-bangkan dalam diri peserta didik berupa nilai-nilai dasar yang disepakati secara nasional. Nilai-nilai yang dimaksudkan di antaranya adalah kejujuran, dapat diper-caya, kebersamaan, toleransi, tanggung jawab, dan peduli kepada orang lain.

Franz Magnis-Suseno, dalam acara Sarasehan Nasional Pengembangan Pen-didikan Budaya dan Karakter Bangsa (14/ 01/2010) mengatakan bahwa pada era sekarang ini yang dibutuhkan bukan hanya generasi muda yang berkarakter kuat,tetapi juga benar, positif, dan konstruktif. Namun, untuk membentuk peserta didik-peserta didik yang berkarakter kuat, tidak boleh ada feodalisme para pendidik. Jika pendidik membuat peserta didik menjadi "manutan" (obedient) dengan nilai-nilai penting, tenggang rasa, dan tidak mem-bantah, karakter peserta didik tidak akan berkembang. Kalau kita mengharapkan karakter, peserta didik itu harus diberi se-mangat dan didukung agar ia menjadi pemberani, berani mengambil inisiatif, be-rani mengusulkan alternatif, dan berani mengemukakan pendapat yang berbeda. Kepada peserta didik, perlu diajarkan cara berpikir sendiri.

Untuk pengembangan pendidikan berbasis karakter dan budaya bangsa, di-butuhkan masukan, antara lain, menyang-kut model-model pengembangan karakter dan budaya bangsa sebagai bagian yang tidak terpisahkan dari sistem pendidikan nasional. Kebutuhan terus harus dimaknai serius karena memerlukan banyak pe-ngorbanan. Kerisauan dan kerinduan banyak pihak untuk kembali memperkuat pendidikan karakter dan budaya bangsa perlu direspons dengan baik. Karena itu, data akurat yang menyangkut model-model pengembangan karakter dan bu-daya bangsa perlu digali dan dilaksanakan melalui kajian empiris, yakni kegiatan pe-nelitian.

Syarat menghadirkan pendidikan karakter dan budaya bangsa di sekolah harus dilakukan secara holistis. Pendidikan karakter tidak bisa terpisah dengan bentuk pendidikan yang sifatnya kognitif atau akademik. Konsep pendidikan tersebut harus diintegrasikan ke dalam kurikulum. Hal ini tidak berarti bahwa pendidikan karakter akan diterapkan secara teoretis, tetapi menjadi penguat kurikulum yang sudah ada, yaitu dengan mengimplementasikannya dalam mata pelajaran dan keseharian peserta didik didik.

\subsection{KARAKTER PESERTA DIDIK YANG DIHARAPKAN}

Karakter dapat diartikan sebagai bawaan, hati, jiwa, kepribadian, budi pe-kerti, perilaku, personalitas, sifat, tabiat, temperamen, dan watak. Karakter dalam pengertian ini menandai dan memfokus-kan pengaplikasian nilai kebaikan dalam bentuk tindakan atau tingkah-laku. Orang yang tidak mengaplikasikan nilai-nilai ke-baikan, misalnya tidak jujur, kejam, rakus, dan perilaku jelek lainnya dikatakan orang yang berkarakter jelek, tetapi orang yang perilakunya sesuai dengan kaidah moral disebut dengan berkarakter mulia.

Karakter peserta didik yang dimak-sudkan dalam tulisan ini adalah karakter mulia yang diharapkan dapat dikembang-kan kepada peserta didik. Dalam hal ini, membangun karakter peserta didik meng-arah pada pengertian tentang mengem-bangkan peserta didik agar memiliki ke-pribadian, perilaku,sifat, tabiat, dan watak baik atau mulia. Karakter yang demikan ini mengacu pada 
serangkaian sikap, perilaku, motivasi, dan kecakapan yang memenuhi standar nilai dan norma yang dijunjung tinggi dan dipatuhi.

Peserta didik yang memiliki karakter mulia memiliki pengetahuan tentang po-tensi dirinya, yang ditandai dengan nilai-nilai seperti reflektif, percaya diri, rasional, logis, kritis, analitis, kreatif dan inovatif, mandiri, hidup sehat, bertanggung jawab, cinta ilmu, sabar, berhati-hati, rela berkorban, pemberani, dapat dipercaya, jujur, me-nepati janji, adil, rendah hati, malu berbuat salah, pemaaf, berhati lembut, setia, bekerja keras, tekun, ulet/gigih, teliti, berinisiatif, berpikir positif, disiplin, antisipatif, ini-siatif, visioner, bersahaja, bersemangat, di namis, hemat/efisien, menghargai waktu, pengabdian/dedikatif, pengendalian diri, produktif, ramah, cinta keindahan (estetis), sportif, tabah, terbuka, tertib. Di samping itu, individu juga memiliki kesadaran untuk berbuat yang terbaik atau unggul dan mampu bertindak sesuai potensi dan ke-sadarannya tersebut. Mereka dapat merealisasikan perkembangan positif sebagai individu (intelektual, emosional, sosial, etika, dan perilaku). Peserta didik yang berkarakter baik atau unggul selalu ber-usaha melakukan hal-hal yang terbaik ter-hadap Tuhan, dirinya, sesama, lingkungan, bangsa dan negara serta dunia internasio-nal pada umumnya dengan mengoptimal-kan potensi (pengetahuan) dirinya dan disertai dengan kesadaran, emosi dan mo-tivasinya (perasaannya).

Keberhasilan program pendidikan karakter dapat diketahui melalui pencapai-an indikator oleh peserta didik sebagai-mana tercantum dalam standar kompetensi lulusan (SKL), yang antara lain meliputi sebagai berikut.

1) Mengamalkan ajaran agama yang di-anut sesuai dengan tahap perkembang-an remaja.

2) Memahami kekurangan dan kelebihan diri sendiri.

3) Menunjukkan sikap percaya diri.

4) Mematuhi aturan-aturan sosial yang berlaku dalam lingkungan yang lebih luas.

5) Menghargai keberagaman agama, bu-daya, suku, ras, dan golongan sosial ekonomi dalam lingkup nasional.

6) Mencari dan menerapkan informasi dari lingkungan sekitar dan sumber-sumber lain secara logis, kritis, dan kreatif.

7) Menunjukkan kemampuan berpikir logis, kritis, kreatif, dan inovatif.

8) Menunjukkan kemampuan belajar secara mandiri sesuai dengan potensi yang dimilikinya.

9) Menunjukkan kemampuan menganalisis dan memecahkan masalah dalam kehidupan sehari-hari.

10) Mendeskripsikan gejala alam dan so-sial.

11) Memanfaatkan lingkungan secara ber-tanggung jawab.

12) Menerapkan nilai-nilai kebersamaan dalam kehidupan bermasyarakat, ber-bangsa, dan bernegara demi terwujud-nya persatuan dalam negara kesatuan Republik Indonesia.

13) Menghargai karya seni dan budaya nasional.

14) Menghargai tugas pekerjaan dan me-miliki kemampuan untuk berkarya.

15) Menerapkan hidup bersih, sehat, bugar, aman, dan memanfaatkan waktu luang dengan baik.

16) Berkomunikasi dan berinteraksi secara efektif dan santun.

17) Memahami hak dan kewajiban diri dan orang lain dalam pergaulan di masya-rakat; menghargai adanya perbedaan pendapat. 
18) Menunjukkan kegemaran membaca dan menulis naskah pendek sederhana. Menunjukkan keterampilan menyi-mak, berbicara, membaca, dan menulis dalam bahasa Indonesia dan bahasa Inggris sederhana.

19) Menguasai pengetahuan yang diperlukan untuk mengikuti pendidikan me-nengah.

20) Memiliki jiwa kewirausahaan.

\subsection{PENDIDIKAN BERBASIS KARAKTER DAN BUDAYA BANGSA}

Pada hakikatnya, pendidikan karakter merupakan suatu sistem pendidikan yang berupaya menanamkan nilai-nilai luhur kepada warga sekolah yang meliputi komponen pengetahuan, kesadaran atau ke-mauan, dan tindakan untuk melaksanakan nilai-nilai tersebut. Dalam pelaksanaan pendidikan karakter di sekolah, semua komponen sekolah harus dilibatkan, ter-masuk komponen-komponen pendidikan itu sendiri, yaitu isi kurikulum, proses pembelajaran dan penilaian, penanganan atau pengelolaan mata pelajaran, pengelo-laan sekolah, pelaksanaan aktivitas atau kegiatan kokurikuler, pemberdayaan sa-rana prasarana, pembiayaan, dan etos kerja seluruh warga sekolah/lingkungan.

Dalam pendidikan karakter dan budaya bangsa ini, segala sesuatu yang di-lakukan guru harus mampu mempengaruhi karakter peserta didik. Sebagai pembentuk watak peserta didik, guru harus menunjukkan keteladanan. Segala hal tentang perilaku guru hendaknya men-jadi contoh bagi peserta didik. Misalnya, cara guru berbicara atau menyampaikan materi, cara guru bertoleransi, dan ber-bagai hal terkait lainnya. Tujuannya adalah membentuk pribadi anak agar menjadi manusia yang baik, warga masyarakat, dan warga negara yang baik.

Kriteria manusia yang baik, warga masyarakat yang baik, dan warga negara yang baik bagi suatu masyarakat atau bangsa, secara umum didasarkan pada nilai-nilai sosial tertentu, yang banyak di-pengaruhi oleh budaya masyarakat dan bangsanya. Oleh karena itu, hakikat pen-didikan karakter dan budaya bangsa dalam konteks pendidikan adalah pendidikan nilai, yakni pendidikan nilai-nilai luhur yang bersumber dari budaya bangsa sen-diri, dalam rangka membina kepribadian generasi muda.

Pendidikan karakter berpijak dari karakter dasar manusia, yang bersumber dari nilai moral universal (bersifat absolut) yang disebut sebagai kaidah emas (the golden rule). Pendidikan karakter dapat memiliki tujuan yang pasti apabila berpijak dari nilai-nilai karakter dasar sebagaimana diungkapkan di atas. Penyelenggaraan pendidikan karakter di sekolah harus ber-pijak pada nilai-nilai karakter dasar, yang selanjutnya dikembangkan menjadi nilai-nilai yang lebih banyak atau lebih tinggi (yang bersifat tidak absolut atau bersifat relatif) sesuai dengan kebutuhan, kondisi, dan lingkungan sekolah itu sendiri (Sudrajad, 2010).

Dewasa ini, banyak pihak menuntut peningkatan intensitas dan kualitas pelak-sanaan pendidikan karakter pada lembaga pendidikan formal. Tuntutan tersebut di-dasarkan pada fenomena sosial yang berkembang, yakni meningkatnya kenakalan remaja dalam masyarakat, seperti perkelahian massal dan berbagai kasus deka-densi moral lainnya. Bahkan, di kota-kota besar tertentu, gejala tersebut telah sampai pada taraf yang sangat meresahkan. Oleh karena itu, lembaga pendidikan formal sebagai wadah resmi pembinaan generasi muda diharapkan dapat meningkatkan peranannya 
dalam pembentukan kepribadi-an peserta didik melalui peningkatan intensitas dan kualitas pendidikan karakter.

Para pakar pendidikan pada umum-nya sependapat tentang pentingnya upaya peningkatan pendidikan karakter pada jalur pendidikan formal. Namun, juga terdapat perbedaan pendapat di antaranya mengenai pendekatan dan modus pen-didikan. Berkaitan dengan pendekatan, sebagian pakar menyarankan penggunaan pendekatan - pendekatan pendidikan moral yang dikembangkan di negaranegara barat, seperti: pendekatan perkembangan moral kognitif, pendekatan analisis nilai, dan pendekatan klarifikasi nilai. Sebagi-an yang lain menyarankan penggunaan pendekatan tradisional, yakni melalui pe-nanaman nilai-nilai sosial tertentu dalam diri peserta didik.

Secara psikologis dan sosial kultural pembentukan karakter dalam diri individu merupakan fungsi dari seluruh potensi individu manusia (kognitif, afektif, konatif, dan psikomotorik) dalam konteks interaksi sosial kultural (dalam keluarga, sekolah, dan masyarakat) dan berlangsung sepanjang hayat. Konfigurasi karakter dalam konteks totalitas proses psikologis dan so-sial-kultural tersebut dapat dikelompokkan dalam: olah hati (spiritual and emotional development), olah pikir (intellectual develop-ment), olah raga dan kinestetik (physical and kinestetic development), dan olah rasa dan karsa (affective and creativity development).

Berdasarkan pembahasan di atas, dapat ditegaskan bahwa pendidikan karak-ter merupakan upaya yang dirancang dan dilaksanakan secara sistematis untuk mem-bantu peserta didik memahami nilai-nilai perilaku manusia yang berhubungan dengan Tuhan, diri sendiri, sesama ma-nusia, lingkungan, dan kebangsaan yang terwujud dalam pikiran, sikap, perasaan, perkataan, dan perbuatan berdasarkan norma-norma agama, hukum, tata krama, budaya, dan adat istiadat.

Menurut Foerster (Koesoema, 2010), terdapat empat ciri dasar dalam pendidikan karakter. Keempat ciri tersebut sebagai be-rikut.

1) Pertama adalah keteraturan interior. Setiap tindakan diukur berdasarkan hierarki nilai. Nilai menjadi pedoman normatif setiap tindakan.

2) Kedua adalah koherensi yang memberi keberanian, membuat seseorang teguh pada prinsip, tidak mudah terombang-ambing pada situasi baru atau takut resiko. Koherensi merupakan dasar yang membangun rasa percaya satu sama lain. Tidak adanya koherensi meruntuhkan kredibilitas seseorang.

3) Ketiga adalah otonomi. Seseorang menginternalisasikan aturan dari luar sampai menjadi nilainilai bagi pribadi. Hal ini dapat dilihat lewat penilaian atas keputusan pribadi, tanpa terpengaruh atau desakan pihak lain.

4) Keempat adalah keteguhan dan kesetiaan. Keteguhan merupakan daya tahan seseorang guna mengingini apa yang dipandang baik dan kesetiaan merupakan dasar bagi penghormatan atas komitmen yang dipilih. Kematangan keempat karakter ini

memungkinkan manusia melewati tahap individualitas menuju personalitas. Orang-orang modern sering mencampuradukkan antara individualitas dan personalitas, an-tara aku alami dan aku rohani, antara in-dependensi eksterior dan interior. Karakter inilah yang menentukan performansi seorang pribadi dalam segala tindakannya. 


\section{METODE: MEMBANGUN PENDIDIKAN KARAKTER BERBASIS KEARIFAN LOKAL}

Era saat ini adalah era global. Untuk menghadapi era global ini, diperlukan in-san bermoral, kompeten, dan unggul. Dalam hal ini, pendidikan merupakan upaya yang paling strategis. Sistem pendidikan nasional dalam batas tertentu telah menghasilkan insan yang berkualitas, misalnya sejumlah orang yang dipercaya untuk menduduki posisi strategis di semua sektor dan di tengahtengah masyarakat. Namun, patut diakui bahwa masih banyak pernyataan yang mengindikasikan sistem pendidikan kita ikut andil akan rendahnya kualitas sumberdaya manusia dan masih merebaknya dekadensi moral yang berdampak terhadap krisis multidimensional.

Untuk meminimalisasi dan memper-kecil, bahkan menghilangkan krisis multidemensional, terutama perilaku tak bermoral yang meluas di masyarakat, kita perlu menata konsep dan implementasi pendidikan nasional. Dalam menjamin pendidikan nasional yang mantap, perlu dijaga konsistensi pendidikan karakter sejak dari landasan filosofis, sistem pendidikan, sampai dengan praktik pendidikan. Tujuan pendidikan tidak hanya menjadikan insan berakal, insan kompeten dan berguna, insan well-adaptive, insan agent of change, dan insan bertaqwa, melainkan insan yang utuh (Wahab, 2010).

Dalam proses pendidikan, peserta didik dipandang sebagai individu yang memiliki potensi moral, mental, fisik, sosial, dan emosional dengan keunikannya. Mereka sebagai co-subject-object yang memiliki kebebasan memilih. Karena itu, kuri kulum pendidikan tidak hanya berupa kurikulum yang bererientasi pada peseta didik, masyarakat, atau pengetahuan dan teknologi, tetapi merupakan kurikulum eklektik dan komprehensif yang mencakup keempat ranah tersebut (student, society, technology, and spiritual oriented curriculum).

Dalam membangun dan menanamkan budaya bangsa kepada peserta didik, pendidik dan tenaga kependidikan menjadi agen perubahan. Guru tidak hanya kompeten, tetapi juga menjadi teladan (sikap, pikiran, dan perilaku), kreatif, dan well adaftif (profesional yang utuh). Demikian juga, ia mengupayakan terus untuk peningkatan diri. Konselor harus benar- benar profesional, yang selalu siap untuk membantu pengembangan diri peserta didik secara optimal dalam melakukan aktualisasi diri. Kepala sekolah harus memiliki principle leadership, disiplin, model, dan supervisonship skill. Kinerja pustakawan dan laboran/teknisi harus memliki jiwa dan sikap yang helpfull. Di samping itu, dalam pelaksanaan pendidikan, harus tersedia ahli terkait (psikolog, dokter) yang ramah dan suka membantu. Pengelolaan pendidikan perlu di upayakan prinsip keadilan, kebermaknaan dan keberamahan pada lingkungan. Pengelolaan pendidikan yang demikian dapat diupayakan melalui pendidikan yang berbasis sekolah dan berbasis masyarakat (sadar nilai) dengan pertimbangan balanced centralization-decentralization yang tetap menempatkan kepentingan daerah. Proses pendidikan dilakukan secara terpadu dengan menjadikan spiritualitas sebagai ruhnya. Dalam pembelajaran, perlu dilakukan penambahan durasi waktu efektif belajar sebagai konsekuensi logis orientasi keluaran (output) yang unggul. Di samping itu, pengelolaan pendidikan harus dilakukan 
secara transparan, adil, dan akuntabel. Untuk itu, dalam proses pendidikan perlu dilibatkan orang tua dan masyarakat, baik dalam aspek akademik, maupun aspek nonakademik (terutama aspek moralitas).

Dalam penilaian pendidikan, tidak hanya difokuskan pada hasil pendidikan tetapi juga kepada masukan (input) dan proses (penilaian komprehensif). Penilaian pendidikan tidak hanya pada aspek akademik, tetapi juga aspek nonakademik (terutama moral menjadi penentu). Karena itu penilaian pendidikan sebaiknya tidak hanya dilakukan oleh guru, melainkan juga peserta didik, pendidik dan tenaga kependidikan lainnya, bahkan jika mungkin melibatkan orang tua. Dalam kegiatan penilaian, tidak hanya dilakukan hanya untuk kepentingan yang bersifat judgmental, tetapi juga bersifat apresiatif dan rekognitif.

Dalam membangun karakter budaya bangsa, lingkungan pendidikan harus mengarah pada penciptaan lingkungan keluarga yang sarat dengan nilai (agama budaya, dan kebangsaan). Kehidupan di lingkungan sekolah harus mengupayakan lingkungan sekolah yang kondusif bagi pengembangan nilai. Dalam hal ini, se-kolah harus mampu mengondisikan ling-kungan masyarakat dengan nilai-nilai yang baik dan mengendalikannya dengan me-mainkan peran filter terhadap nilai-nilai asing yang masuk. Di samping itu, pe-mangku kepentingan pendidikan harus dapat mengawal isi media masa yang memberikan manfaat bagi penyebaran nilai-nilai dan mengendalikan isi media masa yang berpotensi merusak kepribadi-an anak dan bangsa.

Dalam melaksanakan pendidikan berbasis karakter dan budaya bangsa, strategi pengembangan pendidikan perlu mengonseptualisasikan individu sebagai makhluk utuh dengan menekankan pen-tingnya aspek moral. Proses pendidikan harus diupayakan untuk pendidikan nilai sedini mungkin dan sepanjang hayat. Program pendidikan dan kurikulum harus dikembangkan secara terpadu sesuai dengan latar belakang sosial budaya dengan menempatkan nilai moral menjadi ruhnya. Aktivitas keseharian harus menempatkan pimpinan institusi dan pen-didik menjadi model dan bertindak adil, amanah, dan kasih sayang. Pembelajaran hendaknya mampu menciptakan gerakan pendidikan nilai dan mengawalnya secara berkesinambungan, baik dalam konteks pendidikan formal, informal, maupun non-formal. Proses pendidikan hendaknya mem-berikan orientasi peserta didik baru dan melepas lulusan setiap jenjang pendidikan dengan materi nilai-nilai yang dapat di-terima di masyarakat. Agar peserta didik tidak tercerabut dari akar budayanya, pen-didikan perlu menginternalisasikan nilai-nilai yang dijunjung tinggi di masyarakat selama dalam proses pembelajaran dan pendidikan dengan mengupayakan ling kungan fisik dan sosial yang bersih dan menarik.

\section{PEMBAHASAN : LINGKUNGAN SEBAGAI SUMBER PEMBELAJARAN KEARIFAN LOKAL}

Peserta didik sebagai manusia yang utuh memiliki potensi diri, baik sebagai pribadi maupun anggota masyarakat. Potensi diri tersebut akan dapat berkembang dengan baik jika diupayakan secara optimal melalui proses pendidikan. Melalui pendidikan ini, peserta didik akan dapat diarahkan menjadi sosok pribadi yang memiliki kompetensi majemuk sehingga dapat tumbuh dan berkembang 
menjadi anggota masyarakat yang mampu me-mecahkan persoalan hidupnya. Dalam hal ini, kunci utamanya adalah aktivitas pem-belajaran di sekolah.

Pertumbuhan dan perkembangan peserta didik melalui belajar tidak hanya terjadi di bangku sekolah yang terbatas oleh dinding-dinding kelas. Namun, proses pembelajaran bagi peserta didik dapat terjadi pula di lingkungan sekitar, yakni aktivitas peserta didik di luar kelas. Pembelajaran yang dikungkung di dalam kelas sering menciptakan kejenuhan pada diri peserta didik karena mereka merasa ber-ada di dunia lain yang bukan dunianya. Di dalam kelas, peserta didik merasa kebebasannya dirampas, kesenangannya di-batasi, tertawanya semu, keinginannya dihambat. Akibatnya, kreativitas mereka ter-batas pada upaya memenuhi dan menuruti kemauan sistem belajar yang dituntut sekolah. Peserta didik merindukan kembali ke lingkungannya yang telah menyatu sejak dini dalam keutuhan pribadi yang telah lama membentuknya.

Pembelajaran berbasis lingkungan dapat menjembatani peserta didik untuk menemukan kembali harapannya. Yang dimaksud pembelajaran berbasis lingkung an adalah suatu strategi pembelajaran yang memanfaatkan lingkungan sebagai sasaran belajar, sumber belajar, dan sarana belajar. Hal tersebut dapat dimanfaatkan untuk memecahkan masalah lingkungan dan untuk menanamkan sikap cinta lingkungan. Pembelajaran tersebut akan sangat efektif jika diterapkan di sekolah dasar. Hal ini relevan dengan tingkat perkembangan intelektual usia sekolah dasar (7-11 tahun) yang berada pada tahap operasional kon-kret. Peserta didik sekolah dasar cende-rung senang bermain dan bergerak sehingga mereka lebih menyukai belajar lewat eksplorasi dan penyelidikan di luar ruang kelas.

Melalui pembelajaran lingkungan, kejenuhan peserta didik dapat diminimalkan dan kecintaan mereka pada lingkung-an akan dapat dibangun kembali. Dengan demikian, aktivitas proses pembelajaran akan lebih bermakna dan dapat mencipta-kan kegairahan peserta didik dalam be-lajar. Dengan kegairahan belajar tersebut, aktivitas berpikir semu dan pemahaman verbalistik peserta didik terhadap konsep yang dipelajari dapat diminimalkan sehingga peserta didik secara optimal akan dapat memperoleh pengalaman belajar yang sesungguhnya. Pengalaman belajar yang bermakna ini akan dapat dirasakan kembali oleh lingkungan karena pada akhirnya peserta didik juga akan kembali lingkungan masyarakat tempat tinggalnya. Manfaat keberhasilan pembelajaran akan terasa manakala apa yang diperoleh dari pembelajaran dapat diaplikasikan dan di-implementasikan dalam realitas kehidup-an. Inilah salah satu sisi positif yang me-latarbelakangi pembelajaran dengan pen-dekatan lingkungan.

Dalam pembelajaran lingkungan, peserta didik dapat berpikir secara global, tetapi mereka harus bertindak secara lokal.

Artinya, setiap orang/peserta didik perlu belajar apa pun, bahkan mencari hikmah dari berbagai macam pengalaman bangsa-bangsa lain di seluruh dunia, namun pengetahuan tentang pengalaman bangsa-bangsa lain tersebut dijadikan sebagai pembelajaran dalam tindakan di lingkungan secara lokal. Dengan cara kerja seperti itu, kita tidak perlu melakukan trial and error yang berkepanjangan, melainkan kita belajar dari kesalahan-kesalahan orang lain, sementara kita sekadar meneruskan kerja dari paradigma yang benar. 
Bekerja dan belajar yang berbasis lingkungan sekitar memberikan nilai lebih, baik bagi si pembelajar itu sendiri maupun bagi lingkungan sekitar. Misalnya, belajar ilmu sosial atau belajar ekonomi, maka lingkungan sosial dan ekonomi sekitar dapat menjadi laboratorium alam. Pembelajaran ini dapat dilakukan sembari melakukan pemberdayaan (empowering) terhadap kehidupan sosial dan ekonomi masyarakat, sementara si pelajar dapat me-lakukan proses pembelajaran dengan lebih baik dan efisien.

\section{TAHAPAN PEMBELAJARAN MELALUI LINGKUNGAN}

Belajar dengan model belajar melalui lingkungan terdiri atas lima tahap, yaitu tahap observasi, tahap pengajuan masalah dan hipotesis, tahap pemecahan masalah, tahap pemantapan konsep, dan tahap evaluasi. Pada tahap observasi ini, peserta didik melakukan pengamatan mengenai lingkungan hidup yang terkait dengan konsep yang akan diselidiki. Pada tahap ini, peserta didik berinteraksi langsung dengan objek konkret sehingga diperoleh hasil amatan yang lebih akurat, mendalam, dan bervariasi.

Pada tahap pemecahan masalah, guru memberikan fasilitas yang diperlukan, mi-salnya alat/media pembelajaran untuk ke-perluan melakukan penyelidikan. Penyelidikan diarahkan untuk menguji hipotesis. Pemecahan masalah tidak selalu harus melalui percobaan, tetapi bila tidak memung-kinkan untuk dilakukan percobaan cukup dengan demontsrasi guru yang diarahkan untuk menjawab pertanyaan atau menguji dugaan peserta didik.

Setelah masalah dipecahkan oleh peserta didik dan hipotesis telah diuji kebenarannya, selanjutnya peserta didik di-ajak melakukan diskusi pleno untuk mem-berikan pemantapan konsep. Pada saat ini, peran guru sangat diperlukan untuk mem-berikan penegasan terhadap konsep yang benar dan konsep yang salah. Pada tahap ini, guru meminta peserta didik untuk membuat kesimpulan dan rangkuman serta latihan. Latihan ditujukan untuk pe-ngembangan konsep dan memantapkan konsep. Pada tahap ini, dilakukan penerap-an konsep, yaitu menerapkan konsep un-tuk memecahkan masalah kontekstual.

Evaluasi dalam pembelajaran ini tidak saja dilakukan pada tengah dan akhir semester, tetapi juga dilakukan pada setiap saat pembelajaran. Evaluasi yang dimak-sud adalah penilaian dalam bentuk assessmen outhentic, yaitu menilai semua kinerja peserta didik. Model pembelajaran berbasis observasi memberi peluang bagi guru untuk mengembangkan asesmen autentik. Pada umumnya, penilaian pada ranah kognitif selalu dilakukan dengan cara tes tulis (paper and pencil test), tetapi untuk penilaian kerja ilmiah perlu dikem-bangkan pedoman penilaian (rubrik). Con-toh rubrik penilaian kerja ilmiah di antaranya adalah kemampuan merumuskan hi-potesis, kemampuan merancang percobaan, dan kemampuan melakukan percobaan.

\section{PERENCANAAN DAN PELAKSANAAN PEMBELAJARAN MELALUI INGKUNGAN}

Pembelajaran melalui lingkungan memberikan nilai lebih pada pengembang-an kecakapan hidup peserta didik. Kecakapan hidup yang dimiliki siswa melalui pembelajaran lingkungan ini akan 
mem-bangun karakter peserta didik yang kreatif, bertanggung jawab, dan mandiri. Langkah-langkah pembelajaran tersebut dapat di-lakukan antara lain melalui tahapan sebagai berikut.

1) Guru menjelaskan kepada peserta didik apa dan mengapa pembelajaran berbasis lingkungan penting untuk dilakukan.

2) Guru menentukan dan memetakan kompetensi dasar yang akan dicapai melalui pembelajaran berbasis ling-kungan.

3) Guru sebaiknya menentukan objek pengamatan sesuai dengan kompetensi dasar yang telah ditentukan.

4) Guru menyiapkan format-format pengamatan sesuai dengan objek yang akan diamati.

5) Guru mengajari peserta didik cara menentukan objek pengamatan yang sesuai dengan kompetensi dasar yang akan dicapai.

6) Guru memberikan pengalaman belajar sesuai dengan kompetensi dasar yang akan dicapai.

7) Guru membantu peserta didik dalam presentasi hasil kerja mereka, misal-nya, menyiapkan peralatan/ATK.

8) Guru mempersiapkan format penilaian.

9) Guru memberikan kesempatan kepada peserta didik untuk merefleksikan kegiatan yang telah dilakukan.

Pembelajaran berbasis lingkungan dapat dilakukan dalam berbagai bentuk, mulai dari yang sederhana tidak menyita waktu sampai yang paling kompleks yang memerlukan waktu berhari-hari. Hal ini bergantung pada tujuan pembelajaran dan kondisi setempat. Bentuk-bentuk pembe-lajaran berbasis lingkungan dapat dikem-bangkan dengan cara sebagai berikut.

\section{Pembelajaran Lingkungan Samping Waktu}

Pembelajaran model ini dilakukan di luar jam belajar peserta didik. Ketika pe-serta didik berangkat ke sekolah atau per-jalanan ke mana pun mereka diminta mengamati suatu objek atau suatu peristiwa yang menarik perhatian. Kemudian, di sekolah dia diminta memaparkannya secara lisan atau tertulis. Guru dapat me-nentukan apakah deskripsi tersebut se-ragam bentuknya (semua menulis paragraf pendek) atau bebas. Artinya, peserta didik bebas memilih bentuk ungkapannya (eksposisi, narasi, atau mungkin dalam bentuk puisi). Sebaiknya, pengerjaan tugas tersebut berpasangan atau berkelompok sehingga peserta didik dapat berbagi pengalaman. Kelebihan bentuk pembelajaran ini ialah tidak menyita jam pelajaran, guru tidak kehilangan waktu. Kelemahannya, kegiatan pengamatan peserta didik kurang bisa dipantau.

\section{Pembelajaran Lingkungan Singkat Waktu}

Peserta didik dibagi dalam beberapa kelompok, yang setiap kelompok terdiri atas 4-5 peserta didik. Setiap kelompok ditugasi keluar kelas dalam waktu 10-15 menit untuk mengamati objek berbeda-beda yang ada di lingkungan sekolah dan mencatatnya. Hal yang perlu diamati, mi-salnya, bentuk objek yang diamati, warna; ukuran; bentuk, bahan asal objek tersebut; dan sebagainya. Setelah selesai, mereka kembali ke kelas dan menyempurnakan catatan hasil pengamatan mereka. Setiap 
kelompok berdiskusi menyusun laporan tertulis hasil pengamatan mereka, kemudi-an melaporkan secara lisan di depan kelas. Sebagai penutup, setiap kelompok menulis paragraf deskriptif berdasarkan hasil peng-amatan dan menempelkan hasil di papan tulis.

\section{Pembelajaran Lingkungan Model Eks-kursi Sehari}

MPL ekskursi sehari adalah kegiatan belajar dengan melakukan kunjungan ke suatu objek tertentu atau tempat tertentu dalam waktu satu hari. Para peserta didik pergi bersama-sama dengan bimbingan guru ke suatu tempat yang telah dipro-gramkan sebelumnya. Pilihan tempat kun-jungan tersebut harus didasarkan pada tujuan pembelajaran atau diarahkan pada pencapaian kompetensi dasar tertentu.

Sebelum kegiatan ekskursi dilakukan, guru telah menentukan beberapa kompe-tensi dasar yang akan dicapai dalam kegiatan tersebut. Setiap peserta didik harus mengambil satu kompetensi dasar atau lebih yang menjadi garapannya ketika ia melakukan ekskursi tersebut. Dengan demi-kian, peserta didik dapat memfokuskan ke-giatan sesuai dengan tugas yang menjadi pilihan.

Setelah ekskursi selesai, peserta didik bekerja dalam kelompok yang bidang garapannya sejenis. Kerja peserta didik tersebut dapat menggunakan waktu di kelas, atau lebih baik jika dikerjakan di luar jam pelajaran sekolah. Di kelas, peserta didik tinggal melaporkan hasil kerja kelompok dan mendiskusikannya bersama-sama di kelas. Berdasarkan hasil diskusi tersebut, peserta didik menyempurnakan laporan-nya dan memamerkan hasil kerja tersebut dengan menempelkan di kertas manila untuk di pajang di dinding kelas atau tempat yang telah ditentukan.

\section{Pembelajaran Lingkungan Model Proyek}

MPL Proyek merupakan model pembelajaran terprogram yang memerlukan waktu agak panjang. Dalam proyek tersebut, diperlukan waktu agak lama karena peserta didik terlibat dalam kegiatan yang cukup kompleks. Peserta didik tidak sekedar melakukan pengamatan, tetapi juga melakukan kegiatan-kegiatan lainnya se-bagai konsekuensi dari hasil pengamatan tersebut.

Dalam proyek ini, mungkin sekali peserta didik menemukan berbagai persoalan dan berusaha untuk mencari jalan pemecahannya. Berdasarkan temuannya itu, peserta didik diminta untuk melakukan kegiatan seminar untuk menyampaikan berbagai problema yang dihadapi dan upaya pemecahannya. Karena itu, model pembelajaran ini dalam penggarapannya dapat dilakukan melalui proses konsultasi dan tutorial, yang selanjutnya dikembang-kan dalam proyek seminar hasil pengamatan. 


\section{KESIMPULAN}

Dalam pengembangan pendidikan karakter, diperlukan pemahaman bersama antara pemerintah, lembaga pendidikan, pendidik (guru, orang tua), dan masyarakat mengenai pentingnya pembangunan karakter bangsa. Dalam aktivitas pembelajaran, guru/pendidik memiliki tugas mendesain kondisi pembelajaran sehingga membentuk lingkungan belajar yang men-jamin terwujudnya pendidikan karakter. Dalam hal ini, pembelajaran karakter harus terintegrasi, baik dalam budaya sekolah, kegiatan ekstrakurikuler, maupun kegiatan seharian di rumah dan di masyarakat.

Dalam pengembangan karakter, perlu diperhatikan bentuk-bentuk budaya bang-sa (pemahaman tentang pengenalan diri, tujuan hidup, interaksi dengan orang - orang di sekitar, dan proses pengambilan putusan). Metode pengembangan pen-didikan karakter dapat dilakukan dengan

(a) proses penyadaran dan pembiasaan; (b) belajar melalui pengalaman; dan (c) me-nyesuaikan dengan karakteristik dan hak peserta didik. Pembentukan karakter bang-sa memerlukan (a) peraturan yang membentuk suatu ulur yang menjaga integritas akademis lembaga pendidikan; (b) pengem-bangan kemampuan peserta didik untuk berpikir kritis agar menjadi pelajar yang mampu memaknai berbagai pengetahuan dan informasi secara baik dan bijak; dan (c) pengembangan desain sistem evaluasi aka-demik (tentang kenaikan dan kelulusan) yang mampu menjadi solusi alternatif sis-tem penilaian yang benar-benar mampu memotret kemampuan peserta didik.

Pembentukan karakter dimulai dari keinginan untuk mengetahui serta melakukan hal yang baik agar tercipta kebiasaan, baik dihati, pikiran, maupun perilaku. Dalam membentuk karakter positif, peserta didik perlu mengetahui alasan mengapa berbuat baik, merasakan hal yang baik, dan melakukan hal yang baik. Perlunya lingkungan belajar yang positif dan peduli yang ditandai dengan penuh kasih sayang, penuh dengan kepedulian, kompetensi guru dan staf sekolah yang memberikan inspirasi dan bebas dari berbagai bentuk tindak kekerasan, serta pendidikan yang inklusif.

\section{DAFTAR PUSTAKA}

[1] APPI. 2010. Rekomendasi Peran Pendidikan dalam Pembangunan Karakter Bangsa. Konferensi dan Workshop tentang Peran Pendidikan dalam Pemba-ngunan Karakter Bangsa pada 16-17 Oktober 2010 di Universitas Negeri Malang (UM).

[2] Budimansyah, D. 2007. "Pendidikan Demo-krasi Sebagai Konteks Civic Education di Negaranegara Berkembang", Jur-nal Acta Civicus, Vol.1 No.1, hlm.11-26.

[3] Depdiknas. 2003. Undang-undang Sistem Pendidikan Nasional. Jakarta: Pusat Dokumentasi Depdiknas.

[4] Depdiknas. 2005. Undang-undang Guru dan Dosen. Bandung: Adicita Karya Nusa.

[5] Depdiknas. 2007. Pedoman Penilaian Guru dalam Jabatan. Jakarta: Direktorat Pe-ningkatan Mutu Pendidik dan Te-naga Kependidikan.

[6] Koesoema, Doni. 2010. Pendidikan Karakter. Roma: Fakultas Ilmu Pendidikan Universitas Kepausan Salesian. 
[7] Raka, I.I.D.G. 2008. Pembangunan Karakter dan Pembangunan Bangsa: Menengok Kembali Peran Perguruan Tinggi. Ban-dung: Majelis Guru Besar ITB.

[8] Sudrajat, Akhmad. 2010. "Tentang Pen-didikan Karakter" (dalam http://akhmadsudrajat.wordpress.com/2010/-08/20/pendidikan-karakter-di smp) diakses 18 Oktober 2010.

[9] Sudrajat, Akhmad. 2010. "Indikator Keber-hasilan Program Pendidikan Karak-ter" (dalam http://akhmadsudrajat.-wordpress.com/2010/08/20/pendidi kan-karakter-di-smp/) diakses 18 Oktober 2010.

[10] Sukarno. 1965. Di Bawah Bendera Revolusi. Jakarta: PanitIa Penerbit Di Bawah Bendera Revolusi.

[11] Supriadi, Dedi. 1998. Mengangkat Citra dan Martabat Guru. Bandung: Adicita Karya Nusa.

[12] Wahab, Rochmat. 2010. "Membangun Pen-didikan Karakter Berbasis Kearifan Lokal" (dalam http://pagenjahan.-blogspot.com/2010/07/makalah-se-minar-nasional-pendidikan-2.html) diakses 18 Oktober 2010.

[13] Widodo, Rachmad. 2010. "Benarkah Pen-didikan Kita Mengabaikan Pendidik-an Karakter" (dalam http://wyw1d.-wordpress.com/2010/01/24/benark ah-pendidikan-kita-mengabaikanpendidikan-karakter/) diakses 18 Oktober 2010.

[14] Winataputra, U.S. dan Budimansyah, D. 2007. Civic Education: Konteks, Landas-an, Bahan Ajar, dan Kultur Kelas. Ban-dung: Program Studi Pendidikan Ke-warganegaraan SPs UPI. 